\title{
Tubercle of Carabelli: A Review
}

\author{
André Correia and Carla Pina \\ Faculty of Dental Medicine, University of Porto. \\ Rua Dr. Manuel Pereira da Silva, 4200 Porto, Portugal
}

ABSTRACT The tubercle of Carabelli is an important morphological characteristic in the studies of dental morphology and forensic medicine. This trait has been used as an anthropological measure. The purpose of this work is to make a review of the information available about this dental characteristic. Its morphology, genetic characteristics and frequency are discussed in this article.

The great number of works published with emphasis on this dental trait reflects its importance in dental morphology. The tubercle of Carabelli is to dental morphology what the $\mathrm{ABO}$ blood group system is to serology (Scott and Turner, 2000).

This morphological trait was first described in 1841, by Georg Carabelli Edlen von Lunkaszprie (Johnson, 1999). However, other authors indicate that 1842 was the date for the first reference of this dental structure (Kraus, 1959; Bang, 1972; Mizoguchi, 1993; Woelfel, 1997). Georg Carabelli (1787-1842), was an Hungarian syphilologist (syphilis then being rampant in Hungary and elsewhere) and dermatologist (Hoffman, 1968; Della Serra, 1976). Carabelli also was a professor of dental surgery in the Petrograd Academy (Mizoguchi, 1993) and was court dentist to the Austrian Emperor Franz (Johnson, 1999).

Other monographs on syphilis, for exampleSabourad (1917), likewise claim that this dental characteristic is a pathognomonic sign of hereditary syphilis (Corrêa, 1921; Campbell, 1925; Della Serra, 1976; Diamond [cited by Hanke, 1987]). This fact explains the designation of tubercle of Carabelli as the "sign of Sabouraud." However, authors like Cruet, Jeanselm, Mozer, Chenet, Bardoin, De Granda, Gallipe and Mantoux did not agree with this theory (Campbell, 1925; Della Serra, 1976).

\section{NOMENCLATURE}

Numerous synonyms have been used to refer to this dental trait. We encountered the designations of ectocone of Chardin, ectocone of Trihland, pericone of Stehlin (Ferreira, 1996), tuberculum anomalum, fifth lobe, supplementary cusp, fifth tubercle (proposed by Cruet after descriptions by Malassez and Magitot [Della Serra, 1976]), accessory cusp, mesiolingual elevation or prominence, fifth cusp, tuberculum Carabelli, Carabelli's anomaly, tubercle and cusp of Carabelli (introduced by Sömmerling [cited in Dokládal, 1983] in honor of Carabelli's discovery), protuberance of Carabelli,

Editor's note: Mr. Correia and Ms. Pina's paper was awarded Honorable Mention for 2001 in the Albert A. Dahlberg student research competition sponsored by the Dental Anthropology Association.
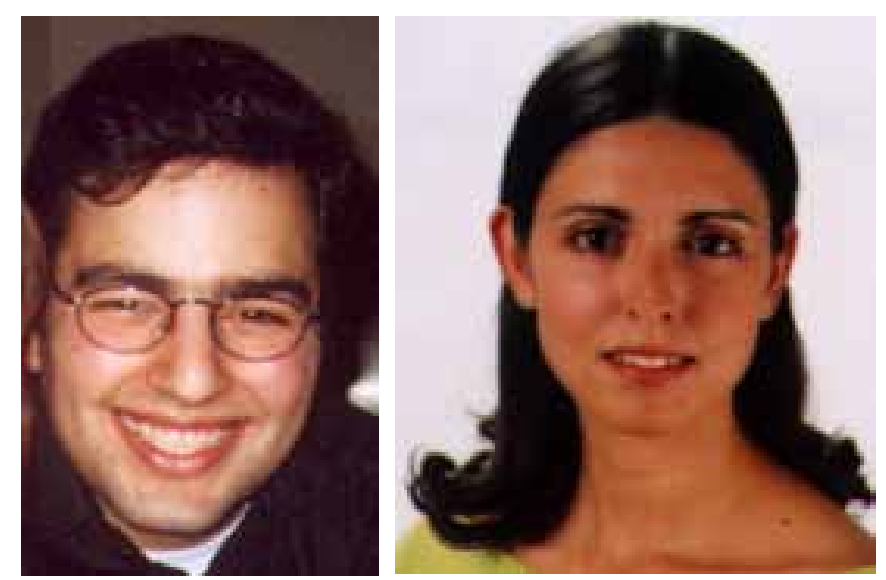

André Correia and Carla Pina

Carabelli's complex, polymorphism of Carabelli (Mizogushi, 1993), tuberculus anomalus (used by Georg Carabelli Edlen von Lunkaszprie [Campbell, 1925]), mesiolingual tubercle, paramolar tubercle, odd tubercle, and atrophied cusp (Hanke, 1987).

Functionally, terms like Carabelli's cusp, fifth cusp, atrophied cusp, supplementary cusp and accessory cusp are incorrect given their position on the lingual side of the crown, which is about $2 \mathrm{~mm}$ lower than the occlusal level (Fig. 1B) (Woelfel, 1997). In the present study, the term Carabelli's tubercle is used to designate this morphological characteristic.

During tooth odontogenesis, some cells of the inner enamel epithelium of the crown base (zona cingularis) retain a proliferative capacity. The development in this region of supernumerary cusps and styles is easily understood, as for example, the tubercle of Carabelli (Abrams, 1992; Pinkerton, 1999; Scott and Turner, 2000). However, in case of an absence of development of a lingual cingulum, this region may or may not form a Carabelli groove (Abrams, 1992).

\section{CLASSIFICATION}

In contrast to the stability of its position on the molar, this trait presents various forms, which makes its pattern difficult to establish. Initially, references to this characteristic only considered the presence-and-absence of the tubercular and lobular forms (nominal scale). 

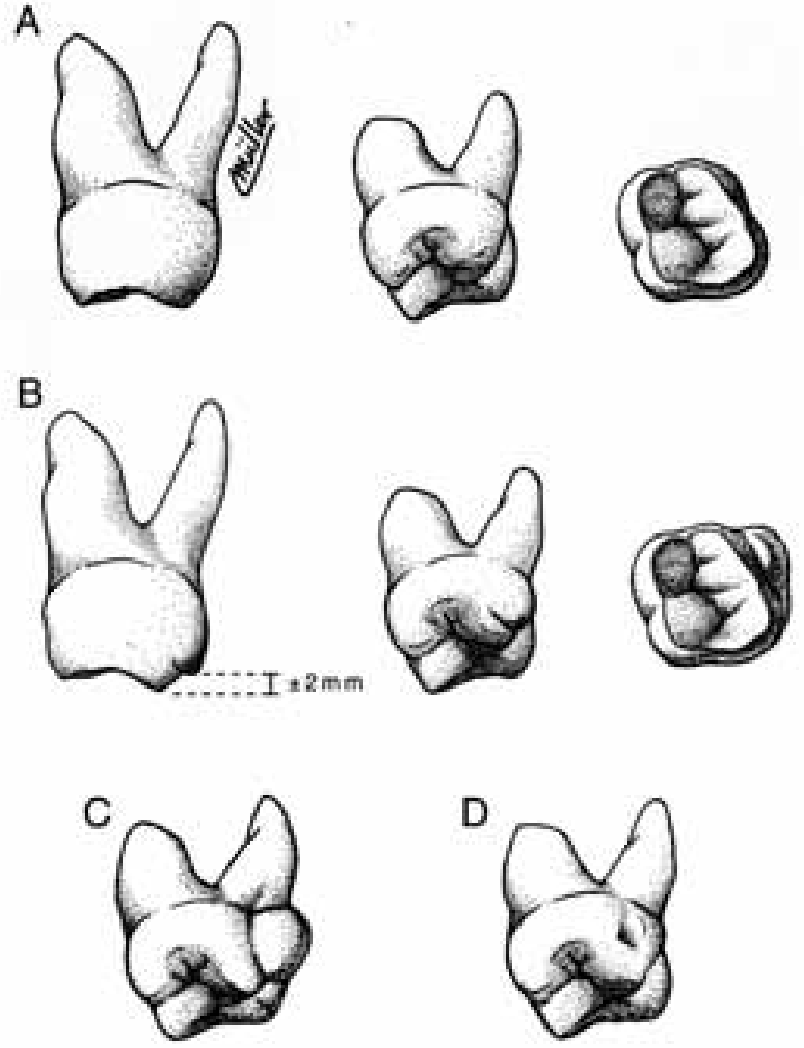

Fig. 1. Views of a maxillary molar showing (A) mesial, mesial-occlusal and occlusal aspects of a tooth without the Carabelli trait, (B) relationship of the Carabelli tubercle on the mesial-lingual crown aspect (with measurement of cusp height relative to the crown's occlusal surface), (C) a mesial-occlusal view of a molar with Carabelli's lobule, and (D) a mesial-cclusal view with Carabelli's groove. (Illustration by Daniel M $\square$ ller, MA.)

However, Batujeff (cited in Kraus, 1959) considered pits and grooves to be manifestations of this feature. This perspective has been supported by other investigators, like Dietz (1944) and Della Serra (1951).

Dahlberg (cited in Scott and Turner, 2000) developed an ordinal scale with eight grades, from trait absence (0) up to a large tubercle (7). All the grades formed a continuum, varying in the degree of expression, as in the ordinal grades developed by Mizoguchi (1993). Perhaps because of the variety of classifications described in the literature, it is difficult to find precise morphological criteria that permit objective comparisons among studies. Using the classification of Dietz (1944), we have compiled the data presented in Table 1.

\section{POPULATION FREQUENCIES}

The tubercle of Carabelli is a phylogenetically ancient characteristic (Pereira, 1995). Jeanselm and De Granda (cited in Della Serra, 1976) documented the presence of this tubercle in skulls of all eras, the first author reported trait from the remains of Adventicious denticulus which was a lemur. It also has been reported in specimens of Pithecanthropus sp. and in other Anthropoids (Corrêa, 1921). Gregory (cited in Campbell, 1925) demonstrated the importance of the tubercle of Carabelli in the structural and phylogenetic relationships between primitive and more recent Anthropoids and Hominoids. Schwartz et al. (1998) studied the tubercle of Carabelli in the Australopithecus (A. africans and P. robustus) and De Terra (cited in Corrêa, 1921) considered this dental characteristic as a sign of civilized races, of which the Krapina man was used as an example.

From an evolutionary perspective, the tubercle of Carabelli tends to disappear in concert with reduction of the hypocone (Fig. 1A), resulting in simplification of the occlusal surface (Reid et al., 1991; Mizoguchi, 1993; Hillson, 1996; Tsai et al., 1996).

From a functional point of view, the tubercle is a compensatory structure of evolution reducing the mesiodistal diameter of upper molars as a result of excessive biomechanical stress exerted on the first molar (Mizoguchi, 1993; Tsai et al., 1996).

The difference in the expression of the Carabelli's tubercle in the primary and permanent dentitions is a decreased frequency but with an elevated proportion of the tubercular form in the permanent dentition.

As an anthropological measure, the tubercle of Carabelli, in conjunction with other morphological traits has been used for the evolutionary study of races (De Castro, 1989; Johnson, 1999; Bailey, 2000). Some characteristics of dental crowns were present or absent in various racial groups, with a great frequency

TABLE 1. Frequency of different expressions of Carabelli's tubercle

\begin{tabular}{lcccc}
\hline \multicolumn{1}{c}{ Author(s) } & Tubercle & Lobe & Groove & Pit \\
\hline Campbell (1925) & 5.0 & 5.0 & 90.0 & -- \\
Campbell (1925) & 23.8 & 35.7 & 40.5 & -- \\
Cohen (cited in Della Serra, 1976) & 17.4 & -- & -- & 44.8 \\
Della Serra (1976) & 5.3 & 2.1 & 30.1 & 23.6 \\
Dietz (1944) & 31.1 & 55.3 & 8.0 & 5.5 \\
Ferreira (cited in Della Serra, 1976) & 29.2 & -- & 29.2 & - \\
Ferreira (cited in Della Serra, 1976) & 18.1 & -- & 33.3 & -- \\
Sharma (1983) & 0.0 & -- & 5.8 & -- \\
\hline
\end{tabular}


that were viewed as identifying characteristics of these groups. For example, in Caucasians the frequency of tubercle of Carabelli is elevated, while the same was not true of the Mongol and in the Melanesian races where the tubercle can reach the size of the other cusps (Kraus, 1959; Abrams, 1992; Tsai et al., 1996). Consequently, the trait can be relevant for dental and racial identification (Table 2).

In studies where the presence or absence of tubercle of Carabelli was quantified, the trait is found more commonly on the first molar. Occurrence of the tubercle on the second molar only occurs when it is also encountered on the first molar (Dietz, 1944).

The differences in population frequency should be considered in terms of differential frequencies of genes regulating the velocity and duration of mitotic cell activity of the zona cingularis (Kraus and Jordan cited in Scott and Turner, 2000).

At the beginning of the last century, G.V. Black (cited in Bailit, 1980) confirms that this dental trace "was hereditary, appearing regularly in children's teeth, when it was present in the parent's teeth. Also it is found, in a modified way when it is present in only one progenitor."

Kraus (1959), in his first analysis, suggested a model of simple autosomal transmission corroborated by other studies. He also considered, that the homozygous condition was responsible for a marked tubercle and that the heterozygous genotype determined the presence of small grooves, pits, tubercles or lobules (Figs. 1C and 1D). Much later, Lee and Goose (1972), Townsend and Brown (1981) and Pinkerton et al. (1999) proposed a multifactorial model in which, in spite of a strong genetic contribution, the environmental factors contributed to the expression of the characteristic. The high bilateral expression of Carabelli's tubercle in twins (Townsend and Martin, 1992; Pinkerton et al., 1999) and the high level of symmetry that has been found in various studies (Dietz, 1944; Scott, 1980) emphasize the importance of a genetic contribution to trait expression, without overlooking environmental factors.

The results of studies by Mizoguchi (1977), Townsend (1981), Kaul and Prakash (1981), Scott and Potter (1983), Tsai et al. (1996), and Pinkerton et al. (1999) document the existence of sex dimorphism in the expression of the tubercle of Carabelli, namely that there is greater prevalence in males. On the other hand, Scott (1980), Castro (1989) and Tsai et al. (1996) did not report any significant difference between the sexes.

\section{SUMMARY}

The tubercle of Carabelli is a morphological dental characteristic with relevance in anthropological and forensic studies. The study of its distribution

TABLE 2. Frequency of Carabelli's tubercle on the maxillary first molar

\begin{tabular}{llc}
\hline \multicolumn{1}{c}{ Author(s) } & \multicolumn{1}{c}{ Samples } & $\begin{array}{c}\text { Frequency } \\
\text { (Percentage) }\end{array}$ \\
\hline Bang (1972) & Eskimos, Alaska & 42.7 \\
Campbell (1925) & Aboriginal Australians & 33.2 \\
Corrêa (1921) & Portuguese & 13.5 \\
Della Serra (1976) & White Australians & 54.4 \\
Dietz (1944) & American soldiers & 72.3 \\
Dokládal (198.3) & Romanian & 52.0 \\
Ferreira (cited in Della Serra, 1976) & Whites, Brazil & 58.4 \\
Ferreira (cited in Della Serra, 1976) & Negroes, Brazil & 51.4 \\
Hanke (1987) & Brazilian population & 58.3 \\
Kaul (1981) & Jat, India (primary teeth) & 79.8 \\
Kaul (1981) & Jat, India (permanent teeth) & 61.9 \\
Reid (1991) & Kwengo & 57.0 \\
Scott (1980) & Eskimos and Aleuts & 47.3 \\
Scott (1980) & Indians, Asia & 62.2 \\
Scott (1980) & Indians, American Southwest & 66.9 \\
Scott (1980) & Easter Island & 35.7 \\
Scott (1980) & Solomon Islands & 44.2 \\
Scott (1980) & Hawaiians & 45.4 \\
Scott (1980) & American White & 85.0 \\
Scott (1980) & Bantu & 73.1 \\
Scott (1980) & Bushmen & 70.3 \\
Scott (1980) & Whites, South Africa & 74.9 \\
Scott et al. (1983) & Pima Indians & 74.0 \\
\hline
\end{tabular}


and frequency among populations demonstrates its importance in the research of human evolution. The documentation in the literature regarding its frequencies has permitted the estimation of phylogenetic relationships between populations separated by geographic conditions.

\section{ACKNOWLEDGEMENTS}

The authors gratefully acknowledge the support of Professor Américo Afonso with respect to the elaboration of this article.

\section{REFERENCES CITED}

Abrams L, Jordan RE and Kraus BS. 1992. Kraus dental anatomy and occlusion. St. Louis: Mosby Year Book, p 75, 76, 290, 342-346.

Bailey SE. 2000. Dental morphological affinities among late Pleistocene and recent humans. Dent Anthropol $14: 1-8$.

Bang G, Hasund A. 1972. Morphological characteristics of the Alaskan Eskimo dentition. Am J Phys Anthropol 37:35-40.

De Castro JMB. 1989. The Carabelli trait in human prehistoric populations of the Canary Islands. Hum Biol 61:117-131.

Campbell TD. 1925. Dentition and palate of the Australian Aboriginal. Adelaide: The Hassel Press.

Corrêa AAM. 1921. Notas morfológicas sobre os molares superiores nos Portugueses. Porto: Departamento de Antropologia da Faculdade de Ciências da Universidade do Porto, p 9-16.

Della Serra O. 1976. Anatomia dental. Rio de Janeiro: Artes Médicas, p 133-137.

Dietz VH. 1944. A common dental morphotropic factor, the Carabelli cusp. J Amer Dent Assoc 31:748-789.

Dokládal M. 198.3. Incidence of the Carabelli anomalous tubercle in Romanies (Gypsies). Folia Morphol 31:51-54.

Ferreira F, Costa JP, Figueira F. 1996. A cúspide de Carabelli como característica identificativa. Stoma Lis 40:51-55.

Hanke ED, Henke LL. 1987. Contribuição ao estudo do tubérculo de Carabelli e suas relações com a face oclusal do segundo molar superior. Dens - Fase II 2:19-22.

Hassanali J. 198.2. Incidence of Carabelli's trait in Kenyan Africans and Asians. Am J Phys Anthropol 59:317-319.

Hillson S. 1996. Dental anthropology. Cambridge: Cambridge University Press.

Hoffman KF. 1968. Georg Carabelli (1787-1842). Zahnarztl Prax 19:60 (abstract).

Johnson C. 1999. Hominid evolution, dental anthropology, and human variation. Oral Biology and the Department of Orthodontics, UIC College of Dentistry. http: //www.uic.edu/classes/osci/ osci590/

Kaul V, Prakash S. 1981. Morphological features of Jat dentition. Am J Phys Anthropol 54:123-127.

Kolakowski D, Harris EF, Bailit HL. 1980. Complex segregation analysis of Carabelli's trait. Am J Phys Anthropol 53:301-308.

Kraus BS. 1959. Occurrence of the Carabelli trait in Southwest ethnic groups. Am J Phys Anthropol 17: 117-123.

Lee GTR, Goose DH. 1972. The inheritance of dental traits in a Chinese population in the United Kingdom. J Med Genet 9:336-339.

Mizoguchi Y. 1993. Adaptative significance of the Carabelli trait. Bull Natn Sci Mus, Ser D (Anthrop) 19:21-58.

Pereira A, Afonso A. 1995. Alterações dentárias em populações antigas. Contribuição para o seu estudo. Rev Port Est Cir Maxilofac 36:19-24.

Pinkerton S, Townsend G, Richards L, Schwerdt W, Dempsey P. 1999. Expression of Carabelli trait in both dentitions of Australian twins. Perspectives Human Biol 4:19-28.

Reid C, van Reenen JF, Groeneveld HT. 1991. Tooth size and the Carabelli trait. Am J Phys Anthropol 84:427-432.

Schwartz GT, Thackeray JF, Reid C, van Reenan JF. 1998. Enamel thickness and the topography of the enamel-dentine junction in South African PlioPleistocene hominids with special reference to the Carabelli trait. J Hum Evol 35:523-542.

Scott GR. 1980. Population variation of Carabelli's trait. Hum Biol 52:63-78.

Scott GR, Potter RH, Noss JF, Dahlberg AA, Dahlberg T. 1983. The dental morphology of Pima Indians. Am J Phys Anthropol ;61:13-31.

Scott GR, Turner CG. 2000. The anthropology of modern human teeth: dental morphology and its variation in recent human populations. Cambridge: Cambridge University Press.

Sharma JC. 1983. Dental morphology and odontometry of the Tibetan inmigrants. Am J Phys Anthropol 61: 495-505.

Townsend GC, Brown T. 1981. The Carabelli trait in Australian aboriginal dentition. Arch Oral Biol 26: 809-814.

Townsend GC, Martin NG. 1992. Fitting genetic models to Carabelli trait data in South Australian twins. J Dent Res 71:403-409.

Tsai PL, Hsu JW, Lin LM, Liu KM. 1996. Logistic analysis of the effects of shovel trait on Carabelli's trait in a Mongoloid population. Am J Phys Anthropol 100:523-530.

Woelfel JB, Scheid RC. 1997. Dental anatomy, its relevance to dentistry, 5th ed. Baltimore: Williams \& Wilkins, p 243. 